\title{
IMPACT OF INFILL DEVELOPMENT ON PRICES OF EXISTING APARTMENTS IN FINNISH URBAN NEIGHBOURHOODS
}

\author{
Hannele AHVENNIEMI ${ }^{1, *}$, Kyösti PENNANEN ${ }^{1}$, Antti KNUUTI ${ }^{1}$, \\ Anne ARVOLA ${ }^{1}$, Kauko VIITANEN ${ }^{2}$ \\ ${ }^{1}$ VTT Technical Research Centre of Finland, Espoo, Finland \\ ${ }^{2}$ Department of Real Estate, Planning and Geoinformatics, Aalto University School of Engineering, Espoo, Finland
}

Received 21 October 2015; accepted 27 June 2017

\begin{abstract}
Popularity of infill development is increasing because of the environmental benefits and cost saving potential it provides, which relate to the possibility to use existing infrastructure and services. However, the impact of infill development on value of existing properties has not been studied to a sufficient extent. Therefore, the aim of our study is to analyse whether infill development affects the prices of existing apartments. We carried out statistical analysis based on data from seven case neighbourhoods, and prices of more than 6000 housing transactions from one decade. The results of our analysis do not support the hypothesis of infill development affecting positively existing housing prices, but neither did the study show a significant negative effect. Both amenity effect and negative externalities may provide explanations as to why property values do not change due to infill development.
\end{abstract}

Keywords: infill development, housing prices, urban neighbourhood, property value, price development.

Supplementary material associated with this article can be found, in the online version, at https://doi.org/10.3846/ijspm.2018.1540

\section{Introduction}

Because of the challenges posed by growing cities more focus today is put on developing existing neighbourhoods with infill development (for example Ooi \& Le, 2013; Haaland \& Bosch, 2015). Several studies have shown the environmental benefits of infill construction or transit oriented development, such as decreasing energy consumption and related smaller carbon footprint from transport (for example Clark, 2013; Nahlik \& Chester, 2014; Glaeser \& Kahn, 2010). Another observed benefit of infill development is the cost-effectiveness, as the already existing infrastructure allows developing a neighbourhood with only moderate investment (Nykänen et al., 2012; Biddle, Bertoia, Greaves, \& Stopher, 2006).

Even if a large number of economic and environmental benefits of infill development have been proven, and promoting infill development has been presented as one of the targets of the housing policy of the national government of Finland (Ministry of the Environment, 2016), new housing development is often, however, opposed by residents of the neighbourhood. Resistance to infill devel- opment might occur when residents fear that the community does not benefit from the development or, even worse, the new development might have a negative impact by worsening the amenities of the neighbourhood or by resulting in negative value development of existing dwellings (for example Matthews, Bramley, \& Hastings, 2015). Even if fear of decreasing property values is a common reason behind the claims in planning practice, the impact of new development on existing housing has not been sufficiently studied (Seppälä, 2013).

Our contribution to this research field is to examine, by using case studies, whether new housing developments affect the value of existing apartments in Finnish neighbourhoods. Earlier studies, which are presented in section 1, mainly focus on different type of real estate market (metropolitan cities in the U.S. and Asia) or different housing types (such as single-family houses) and therefore our research is among the first ones to study the impact of infill development on value of dwellings in Nordic urban neighbourhoods.

${ }^{*}$ Corresponding author. E-mail: hannele.ahvenniemi@aalto.fi 


\section{Literature review}

\subsection{Residential property market}

Before studying the impact of infill development on property value, it is important to understand the specific characteristics of real estate as a commodity and the basics of property valuation theories. The specific nature of residential real estate market derives from the fact that housing as a commodity differs greatly from other commodities: First, the decision to buy housing is not only based on rational choice but also on emotions, and therefore difficult to measure in monetary terms. Second, apartments are indispensable commodities, and therefore always demanded. And third, apartments are heterogenic and they always differ from each other in terms of location and other characteristics. Housing as a good is called a differentiated good. This category of goods consists of a diversity of products that differ in characteristics in various ways but are so closely related in consumers' minds that they are considered as one good (Day, 2001). Other characteristics of the real estate market, worth mentioning, are the significantly high transaction costs and asymmetric information.

Basic theories on real estate valuation build on the theory of Von Thünen explaining the farmland value already in 1860s, and on Alonso's (1964), Muth's (1969) and Mill's (1967) monocentric city model theory. The underlying idea of the monocentric city model is that real estate prices are developed based on a bidding process which pushes prices up in attractive locations. Central business districts are often considered as attractive locations, but improved transport infrastructure makes it more attractive to live close to stations (Fejarang, 1994) or highways (Baum-Snow, 2007). Hence, because of increasing mobility and income, densities in central districts have not only been continuously growing, but instead, emerging subcentres have given rise to the development of polycentric cities (for example Bertaud, 2004).

The hedonic pricing methodology introduced by Rosen in the 1970s enable an easier way to understand the theory of property value formation. According to Rosen (1974), the price of a differentiated good is determined by the combination of the implicit prices of the different characteristics. When applying this theory to real estate it is suggested that the price of a real estate will differ from the price of another based on the additional unit of a characteristics existing in one real estate compared to the other.

Property valuation theories present that attributes that have an impact on property prices can be divided into two groups: structural and location-specific attributes (Ki \& Jayantha, 2010). Structural characteristics describe the physical characteristics of a property comprising attributes such as age of the building, floor space, floor level, size of the property, number of bedrooms, and types of property ownership (Tse \& Love, 2000; Camagni \& Capello, 2008). In general, size of the dwelling and floor level have a positive impact on property prices due to increased utility and better view, whereas building age has the opposite effect (Tse \& Love, 2000). Good condition of the building and availability of an elevator are also supposed to increase housing prices significantly (Hülagü, Kızılkaya, Özbekler, \& Tunar, 2015).

Location-specific attributes are related to the surrounding neighbourhood and environment of the property. According to Lönnqvist (2015) these location related attributes can be grouped as public goods, externalities and amenities. A public good is a freely available good, such as nature or public park The consumption of this good does not decrease the possibility of others to consume it. Externalities can be either positive (such as high-quality architecture) or negative (such aspollution or congestion due to improved traffic infrastructure), and the effect is caused to a third, external party. The third group, amenities, comprises a large variety of attributes of the neighbourhood, such as features of the environment and services available in the area. A large number of studies examine the impact of different location-specific characteristics on property values. A summary of the impact of neighbourhood characteristics, which are also relevant for infill development, are presented in the section below.

According to Krause and Bitter (2012), people are willing to pay a price premium for elements related to "compact" development, which seems plausible in the light of the following findings: Vicinity of public transport has been identified as an important attribute positively affecting property values (Debrezion, Pels, \& Rietveld, 2007; Gibbons \& Machin, 2005; McMillen \& McDonald, 2004; Kay, Noland, \& DiPetrillo, 2014; Zhang, Meng, Wang, \& $\mathrm{Xu}, 2014)$, although some studies indicate an insignificant correlation (Thamrongsrisook, 2011; Forrest, Glen, \& Ward, 1996; Zhang, Meng, Wang, \& Xu, 2014; Jun, 2012). Similarly, proximity and accessibility of services have been pointed out as amenities increasing the willingness to pay for housing (Litman, 2014; Cortright, 2009). Shops, schools and railway stations often have a positive impact on housing prices (Brennan, Olaru, \& Smith, 2014; Wen, Zhang, \& Zhang, 2014; Kong, Yin, \& Nakagoshi, 2007; Des Rosiers, Lagana, \& Thériault, 2001). However, the impact of some amenities, such as airports and open air shopping centre, might be seen as more contradictory because of their negative externalities (Kholdy, Muhtaseb, \& Yu, 2014; Espey \& Lopez, 2000). Also the high importance of landscape factors has been discovered in several studies: factors which have been identified as positive are vicinity of green areas (Tyrväinen, 1999; Kong, Yin, \& Nakagoshi, 2007; Kovacs, 2012) and pleasant view (Damigos \& Anyfantis, 2011), whereas close vicinity of high voltage overhead transmission lines might have a strongly negative impact (Han \& Elliot, 2013).

Finally, regarding the apartment ownership, the Finnish residential property market differs from the real estate market in other countries to some extent. Owning an apartment is organised through indirect ownership, a limited company (called housing company), giving the shareholders the right to possess a specified flat. The 
shareholders make the decisions about the property, and in case of infill development, they decide about the provision of land for developers (Falkenbach \& Nuuja, 2007). This is also the reason why the focus of our study is on privately owned apartments; the shareholders are the ones benefiting from the potential value increase and they are also the ones making the decision about selling permitted building volume to developers.

\subsection{Impact of infill development at the neighbourhood and city level}

In this section we give a short summary on impact that infill development can have on a neighbourhood or a city according to earlier research. Starting with the city level benefits, it is often mentioned that infill development provides agglomeration benefits to a city (Rosenthal \& Strange, 2004; Laakso, 2012). Agglomeration benefits are based on the idea, presented by several studies and economic theories, suggesting that tight location of both population and the economy yields efficiency, and hence brings about production and income benefits (Piekkola \& Susiluoto, 2012; Ciccione, 2002). Infill development can provide also other economic benefits to a city: Dye and McMillen (2007) present that redevelopment may increase the tax revenue of a city if old buildings are replaced by new expensive homes. Other suggested city level benefits of infill development are prevention of urban sprawl (Dye \& McMillen, 2007), improvements in the functionality of the city structure and reinforced social stability (Kytö, Kral-Leszczynska, Tuorila, \& Kiuru, 2014).

Both positive and negative impacts of infill development on a neighbourhood have been recognised in earlier studies (for example McConnell \& Wiley, 2010). These impacts are often related to public transport access, landscape value or changes in service provision. Essential regarding our study is the concepts of "spillover effect" or "neighbourhood effect", which suggest that change in land may affect the land value of the neighbouring property on which there have been no improvements or changes (Zahirovich-Herbert \& Gibler, 2014). The same phenomenon can be called amenity effect, which, according to Ooi and Le (2013), occurs when a new development refreshes the neighbourhood making also the existing housing more desirable. If the new development brings along services because of the increased purchasing power (Seppälä, 2013) or improves the access to public transportation, the neighbourhood attractiveness might increase, which might lead into rising property prices. On the other hand, if the new development causes negative externalities, for example by deteriorating the landscape or decreasing the green areas, the value of the nearby properties might suffer. Also, Ooi and Le (2013) present that a "supply effect" might occur if new extensive supply of houses increases the housing stock in the area and creates downward pressure on the value of existing properties. These amenities and dis-amenities are essential when people assess the at- tractiveness of a neighbourhood and, hence, these characteristics also influence the price that a household is willing to pay for an apartment (as was presented in section 1.1).

Finally, in addition to the improved neighbourhood characteristics that infill development may provide, also some direct benefits have been observed. As some Finnish studies suggest, infill development can help housing companies facing future renovations, because selling building permit for infill development provides income which can be used to cover renovation costs (Nykänen et al., 2012; Seppälä, 2013). Hence infill development could provide a solution to the challenges caused by the growing renovation need that Finnish buildings built between the 1960s and 1980s are facing.

\subsection{Earlier studies on impact of infill development on housing prices}

In this section we present a summary of findings from previous research examining the impact of infill development on housing prices. The focus is on the spillover effect of infill development, which according to Ooi and Le (2013) can be estimated by comparing the change in prices of the properties nearby before and after the new development, to the price changes for properties in the control group during the same period of time.

A theoretical study by Nykänen et al. (2013) found that in case that infill development would be $20 \%$ of the size of existing housing stock, the impact on existing housing prices would range from +5 to $+9 \%$. In case of a $50 \%$ infill development, the impact would vary between +10 and $+17 \%$. According to the study, infill development is most profitable in neighbourhoods with lowest housing prices, whereas in central areas with high property prices the potential for price increase has already been used to a large extent.

Only few studies however have empirically proven a significant positive price impact of infill development. Ooi and Le (2013) studied the changes in the wealth of existing homeowners in a neighbourhood with new housing construction in Singapore, and found that infill development has a positive and persistent impact on existing housing prices. While the height of the building imposes negative externalities on the surrounding properties, infill development taking place on a teardown site provides positive externalities. According to the study, a positive spillover effect can also be related to the signals of future amenities in the area. Mathur and Ferrell (2013) studied the impact of sub-urban transit-oriented development (TOD) on single-family home prices in California, the U.S., and present that the positive impact of the TOD is statistically significant. Prices of houses within $1 / 8$ mile of the TOD were $18,5 \%$ higher than of those located more than $1 / 8$ mile from the TOD.

A few studies have examined the impact of government aided revitalisation and other infill projects on deteriorating neighbourhoods. Ryan and Weber (2007) studied the impact of urban development on housing values in 
a low-income neighbourhood in Chicago and found that infill development is more valued than traditional neighbourhood development or enclaves. The suggested reason for this result is that residents value housing which is integrated into its urban context. Ellen, Susin, Schwartz, and Schill (2001) studied the impact of two New York City homeownership programs on the value of surrounding properties. The programs subsidised the construction of affordable owner-occupied homes in distressed neighbourhoods. The study shows that the prices of properties in the vicinity of development projects have risen during two decades and it is suggested that part of this rise is due to the homeownership programs. Suggested potential reasons for the positive externalities are the nicer appearance of the buildings, new higher-income residents and the higher rate of homeownership leading into greater neighbourhood stability and community activism, and better upkeep of the surroundings.

Other studies suggest that the impact of infill development on existing housing prices is minor or insignificant. Zahirovich-Herbert and Gibler (2014), who examined the impact of new construction on existing housing prices in Louisiana, U.S., found that construction of new houses has a positive, but insignificant influence on prices of existing housing. The authors suggest that this is because new houses increase competition and therefore prices of existing houses suffer when new similar sized houses are constructed nearby (also called "supply effect" by Ooi and Le, 2013). However, if the new houses are larger than the existing ones, the prices of old houses are positively influenced because of the location close to these "superior" houses. Another study from the U.S., by Blanchard Clegg, and Martin (2008), found no evidence that infill development would lower the value of surrounding properties, based on the analysis of 12 case neighbourhoods in Idaho. The authors pointed out the difficulties of attributing the price changes directly to infill development, as also many other factors affect the value. Also, insignificant impact were found by Pollakowski, Ritchay, and Weinrobe (2005) who studied the relationship between large-scale, high-density, mixed-income rental developments and single-family home values with case studies from seven towns in the U.S.

Contrary results have been presented also regarding revitalisation projects: a study by Newell (2010) examined the revitalisation possibilities of a Self Help project for a neighbourhood in North Carolina and concluded that residential investment within the neighbourhood creates negative externalities for surrounding properties. The suggested reason is that small scale investment does not create enough positive externalities and hence increasing the housing stock in a neighbourhood with low demand might have a negative impact on the prices of existing housing. The authors also suggest that higher desirability of new construction over old housing stock leads into lower value of older homes.

\section{Methodology and data}

The aim of our study was to analyse whether infill development affects the prices of existing apartments in the chosen case neighbourhoods. To examine the price impact, we carried out statistical analysis based on sale price data from seven case neighbourhoods and appointed reference neighbourhoods in Finnish urban areas located in the capital region. We used difference-in-difference (DD) methodology, applied via a hedonic regression model, to capture the effect of infill development on the price changes in the case neighbourhoods (compared to the reference neighbourhoods).

Data for the study was obtained from a housing transaction database which contains information about actual sale prices of apartments along with information on other attributes, such as size of the apartment, age, number of rooms, condition, floor level and lot ownership and size. These data are voluntarily collected by a consortium of Finnish real estate brokers, and it is maintained by the VTT Technical Research Centre of Finland. The data consists of about 900000 individual transactions from Finland, since 1970, and it represents a comprehensive sample of the total transaction volume. Our study is based on an analysis of more than 6000 transactions, which have taken place in the selected seven case neighbourhoods and the related reference neighbourhoods during the years 1998-2012 (Table 1). The data was geocoded, and by using coordinates, the data was supplemented with a few environmental attributes.

\subsection{Selection criteria for the case neighbourhoods}

To study whether infill development has an impact on the prices of existing apartments, seven case neighbourhoods were selected. The areas were limited by the use of postal codes. The selection of these case neighbourhoods was based on the following criteria:

1. The majority of buildings in the neighbourhood are built between the 1960s and 1980s. This criterion was chosen to maximise the homogeneity of the existing buildings in the neighbourhood and also to facilitate finding a reference neighbourhood with similar type of housing stock. In Finland, a large number of apartment buildings were built during those decades and therefore this time frame seemed reasonable;

2. The neighbourhood has a sufficient number of new developments either in the centre or in the outskirt of the neighbourhood. Here we defined infill development as two or more new apartment buildings built in the neighbourhood. As the definitions for infill development are usually rather broad (for example "infill development takes place on an unconstructed site which takes place in an already constructed area" or "infill development is used to improve the environment and structure of the neighbourhood" (Santaoja, 2004)), the research group decided that two or more apartment buildings are needed to provide any impact; 
3. The neighbourhood has a sufficient number of buildings owned by housing companies (other than companies for social housing/rental apartments) which is a typical way to own flats in Finland (Falkenbach \& Nuuja, 2007);

4. Infill development has taken place between 2000 and 2009. This time frame was chosen for the analysis in order to minimise the effects of other events which might affect the price development (such as the economic depression of the 1990s) and to be able to observe the potential effects on housing prices.

\subsection{Selection of the control neighbourhoods}

Reference neighbourhoods were chosen for each case neighbourhood. The selection criteria for the reference neighbourhoods were as follows: 1) the reference neighbourhood should be located in the vicinity of the case neighbourhood, 2) the reference neighbourhood should be similar to the case neighbourhood regarding the type of housing stock, accessibility and level of service availability, and 3) no infill development has taken place in the reference neighbourhood during the last decade.

The idea behind the used selection criteria for the reference neighbourhoods was that if the main locational attributes such as distance from the centre of the city, accessibility, type of housing stock and level of services are similar in the two neighbourhoods, the price level of apartments should equal, and if not, it is due to a change or an event which is taking place in only one of the neighbourhoods (in this case: infill development).

\subsection{Measures used in the study}

We applied difference-in-difference methodology (Angrist \& Pischke, 2008; Votsis \& Perrels, 2016; Card \& Krueger, 1994) combined with linear regression analysis in our study. First, we formed two group variables: We named the case neighbourhoods (the ones in which infill development has taken place) as treatment neighbourhoods, and reference neighbourhoods (those with no infill development) as control neighbourhoods. We also created a dummy variable for the time before and after infill development. It is essential for the difference-in-difference method to compare two groups which are similar to each other. Hence, the underlying assumption is that as the treatment neighbourhoods and related control neighbourhoods are located close to each other, and they are identical by attributes listed in section 1.2. Also the structure of the housing market and the housing price trends are rather similar in the treatment and control neighbourhoods.

Furthermore, we used hedonic pricing methodology which is the most commonly used method in housing studies. The hedonic pricing method assumes that the price of housing derives from the prices and quantities of its characteristics (Lönnqvist, 2015). We introduced a number of structural variables into the model. These variables describe the physical characteristic of the building/dwelling, (e.g. dwelling condition, floor number/total floors, elevator etc.) and they are typically included in regression models in housing price studies. Additionally, we introduced three environmental variables: distance to $\mathrm{CBD}$ (central railway station of Helsinki), distance to sea cost and distance to green areas (including parks and woods). These are all attributes which, according to earlier research, might have a significant impact on housing prices. form:

The estimated regression equation takes the following

$$
\begin{aligned}
& \mathrm{P}=\alpha+\beta_{1}(\text { CONDITION })+\beta_{2}(\text { ELEVATOR })+ \\
& \beta_{3}(\text { ROOMS })+\beta_{4}(\text { FLOOR })+\beta_{5}(\text { SEA })+\beta_{6}(\text { CBD }) \\
& +\beta_{7}(\text { GREEN })+\beta_{8}(\text { TREAT })+\beta_{9}(\text { AFTER })+ \\
& \beta_{10}\left(\text { TREAT }^{*} \text { AFTER }\right)+\varepsilon
\end{aligned}
$$

\begin{tabular}{|c|c|c|c|c|}
\hline $\begin{array}{l}\text { No. of the } \\
\text { case }\end{array}$ & Name of the neighbourhood & Neighbourhood group & $\begin{array}{l}\text { Period of infill } \\
\text { development }\end{array}$ & $\begin{array}{c}\text { Number of transactions } \\
\text { considered }\end{array}$ \\
\hline 1 & \begin{tabular}{|l} 
Karakallio \\
Viherlaakso
\end{tabular} & $\begin{array}{l}\text { Treatment } \\
\text { Control }\end{array}$ & $2007-2008$ & $\begin{array}{l}161 \\
167\end{array}$ \\
\hline 2 & \begin{tabular}{|l} 
Yliskylä \\
Roihuvuori
\end{tabular} & $\begin{array}{l}\text { Treatment } \\
\text { Control }\end{array}$ & 2004,2009 & $\begin{array}{l}338 \\
174\end{array}$ \\
\hline 3 & $\begin{array}{l}\text { Tapulikaupunki } \\
\text { Siltamäki }\end{array}$ & $\begin{array}{l}\text { Treatment } \\
\text { Control }\end{array}$ & $2000-2001$ & $\begin{array}{l}146 \\
130\end{array}$ \\
\hline 4 & $\begin{array}{l}\text { Pihlajisto-Viikinmäki } \\
\text { Pihlajamäki }\end{array}$ & $\begin{array}{l}\text { Treatment } \\
\text { Control }\end{array}$ & 2001,2004 & $\begin{array}{c}92 \\
217\end{array}$ \\
\hline 5 & $\begin{array}{l}\text { Lauttasaari } \\
\text { Pohjois-Lauttasaari }\end{array}$ & $\begin{array}{l}\text { Treatment } \\
\text { Control }\end{array}$ & $2000-2010$ & $\begin{array}{l}183 \\
345\end{array}$ \\
\hline 6 & $\begin{array}{l}\text { Keski-Vuosaari } \\
\text { Vartioharju } \\
\end{array}$ & $\begin{array}{l}\text { Treatment } \\
\text { Control }\end{array}$ & $2002,2006,2010$ & $\begin{array}{c}374 \\
72 \\
\end{array}$ \\
\hline 7 & $\begin{array}{l}\text { Mikkola } \\
\text { Havukoski }\end{array}$ & $\begin{array}{l}\text { Treatment } \\
\text { Control }\end{array}$ & $2003-2008$ & $\begin{array}{l}152 \\
211\end{array}$ \\
\hline
\end{tabular}

Table 1. Case/treatment neighbourhoods, reference/control neighbourhoods, the period of infill development and number of transactions considered in the study 
where the dependent variable $\mathrm{P}$ is sales price $(1000 €)$ per $\mathrm{m}^{2}$. The independent variables are explained in Table 2 . Epsilon $(\varepsilon)$ stands for normally distributed error term.

The analysis was carried out separately for the seven cases. The studied point in time varied, depending on the timing of the infill development: we used transactions up to five years before and after infill development. A long enough time period before and after was chosen to ensure that 1 ) the expectations due to new developments would not yet have affected the prices in the "before" groups and 2) the potential effects could be observed in the "after" groups. As the number of transactions per year remained rather small, in most cases we used transactions from a two-year period (in few cases it was necessary to study a three-year period). The sale prices were adjusted for inflation using the Consumer Price Index, and with 2012 as the base year.

\section{Result}

Price development of both case neighbourhoods and reference neighbourhoods was analysed by examining the average sale prices before and after infill development. Average sale prices and average duration of apartments being on sale are shown in Table 3. A general price increase can be observed in all treatment and control groups indicating that both groups follow the rising price trend of housing transactions in the capital area of Finland. Also, changes in on-sale times give indication on the development of the housing market in each treatment and control neighbourhood. Longer on-sale time might lead into larger discount and hence, lower sale price. However, as the prices are consistently higher in the "after" cases but on-sale times vary largely (taking both larger and smaller values than in the "before" cases), no consistent logic between the sale prices and on-sale time can be observed.

Table 2. Independent variables and mean values for the neighborhoods

\begin{tabular}{|c|c|c|c|c|c|}
\hline Variable & Description & $\begin{array}{c}\text { Mean } \\
(\mathrm{N}=2762)\end{array}$ & Min & Max & SD \\
\hline CONDITION & $\begin{array}{l}\text { Condition of the dwelling }(0=\text { bad, } 1=\text { average, } \\
3=\text { good })\end{array}$ & 1.754 & 0 & 3 & 1.13 \\
\hline ELEVATOR & Dummy for the elevator $(0=$ no, $1=$ yes $)$ & 0.485 & 0 & 1 & 0.499 \\
\hline ROOMS & Number of rooms, excl. kitchen & 2.373 & 1 & 6 & 0.962 \\
\hline FLOOR & Floor number/ number of total floors & 0.645 & 0.1 & 1 & 0.281 \\
\hline SEA & Distance to the sea cost $(\mathrm{m})$ & 3120 & 22 & 11340 & 3718 \\
\hline $\mathrm{CBD}$ & Distance to the city centre (railway station) (m) & 9881 & 2951 & 21124 & 4894 \\
\hline GREEN & Distance to parks or green areas $(\mathrm{m})$ & 174.5 & 0 & 609 & 142 \\
\hline TREAT & \multicolumn{5}{|c|}{ Dummy for the treatment group $(0=$ control group, $1=$ treatment group $)$} \\
\hline AFTER & \multicolumn{5}{|c|}{ Dummy for the "after infill development" cases $(0=$ before, $1=$ after $)$} \\
\hline
\end{tabular}

Table 3. Mean values of prices and on-sale days for treatment and control groups

\begin{tabular}{|c|c|c|c|c|c|c|c|}
\hline & \multicolumn{2}{|c|}{$\mathrm{PRICE} / \mathrm{m}^{2}$ (thousand $€$ ) } & \multicolumn{2}{|c|}{ On-sale time } & \multicolumn{2}{|c|}{$\mathrm{N}$} \\
\hline & & Before & After & Before & After & Before & After \\
\hline \multirow[t]{2}{*}{ Case 1} & Treatment & 1.919 & 2.384 & 59.4 & 62.8 & 61 & 100 \\
\hline & Control & 1.879 & 2.430 & 68.8 & 70.8 & 58 & 109 \\
\hline \multirow[t]{2}{*}{ Case 2} & Treatment & 2.104 & 2.940 & 43.2 & 53.2 & 117 & 221 \\
\hline & Control & 2.027 & 2.910 & 39.1 & 44.5 & 54 & 120 \\
\hline \multirow[t]{2}{*}{ Case 3} & Treatment & 1.631 & 2.260 & 47.6 & 41.3 & 79 & 67 \\
\hline & Control & 1.835 & 2.296 & 35.9 & 69.9 & 40 & 70 \\
\hline \multirow[t]{2}{*}{ Case 4} & Treatment & 1.612 & 2.396 & 66.2 & 35.8 & 51 & 41 \\
\hline & Control & 1.741 & 2.605 & 47.2 & 46.9 & 149 & 68 \\
\hline \multirow[t]{2}{*}{ Case 5} & Treatment & 2.802 & 4.436 & 30.6 & 72.3 & 45 & 138 \\
\hline & Control & 2.747 & 4.676 & 33.0 & 42.0 & 115 & 230 \\
\hline \multirow[t]{2}{*}{ Case 6} & Treatment & 1.674 & 2.593 & 47.5 & 47.9 & 146 & 228 \\
\hline & Control & 2.140 & 2.949 & 44.7 & 43.7 & 28 & 44 \\
\hline \multirow[t]{2}{*}{ Case 7} & Treatment & 1.184 & 1.758 & 45.6 & 59.3 & 36 & 116 \\
\hline & Control & 1.250 & 2.076 & 73.0 & 41.9 & 117 & 94 \\
\hline
\end{tabular}


Figure 1 illustrates the development of average non-deflated sale prices in case neighbourhood 1 (Karakallio), in the corresponding reference neighbourhood (Viherlaakso) and the sale prices of new apartments in the case neighbourhood. For comparison, also the price index of a larger surrounding area is presented. The graph illustrates how the price development in the case and the reference neighbourhood is very similar during the whole studied time frame, and the development of prices in both neighbourhoods also follow the development of the price index of the wider area. Similar graphs for the seven case neighbourhoods are presented in the Supplementary Appendix 1.
The results from the difference-in-difference hedonic regression are reported in Table 4 . The following observations can be drawn from the regression results: Being located in a neighbourhood in which infill development takes place (TREAT) does not seem to provide higher prices compared to the control neighbourhood. In most cases the effect is insignificant, and in one of the cases with significant effect, the effect is the opposite, and the prices are higher in the control neighbourhood. Furthermore, as was observed also in Table 3, prices are constantly higher after infill development (AFTER) which is in line with the price trend of the whole capital area. The most interesting

Case 1 (Karakallio - Espoo)

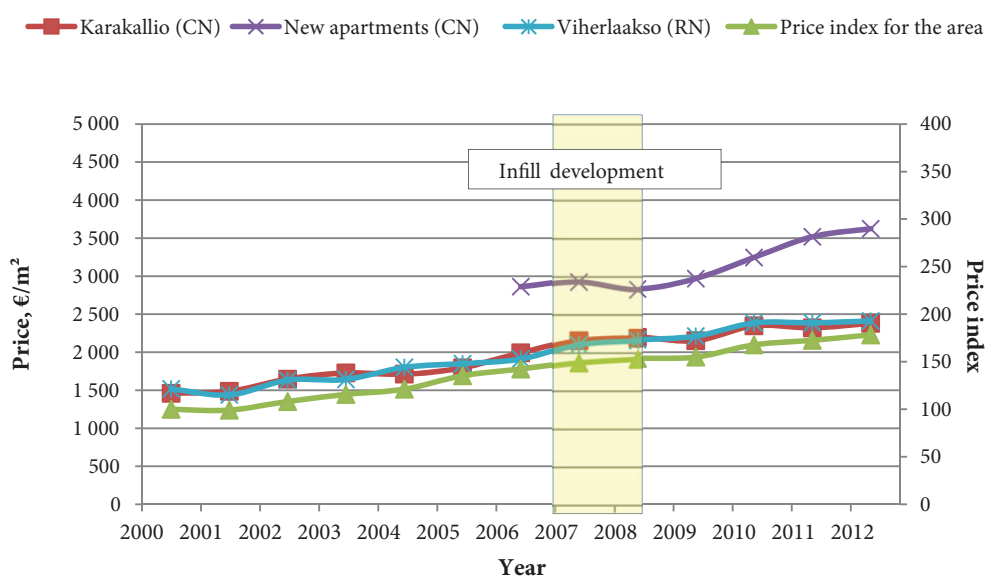

Figure 1. Case 1: Mean values of sale prices $\left(\right.$ by $^{2}{ }^{2}$ ) of old apartments in the case neighbourhood $(\mathrm{CN})$, the reference neighbourhood $(\mathrm{RN})$, new apartments in the case neighbourhood and the price index in the area

Table 4. Results of the difference-in-difference hedonic regression analyses of the seven cases

\begin{tabular}{|c|c|c|c|c|c|c|c|}
\hline & Case 1 & Case 2 & Case 3 & Case 4 & Case 5 & Case 6 & Case 7 \\
\hline CONDITION & $\begin{array}{c}0.0991^{\star * *} \\
(0.0149)\end{array}$ & $\begin{array}{l}0.120^{* \star *} \\
(0.0181)\end{array}$ & $\begin{array}{l}0.0750^{* *} \\
(0.0236)\end{array}$ & $\begin{array}{l}0.050^{* *} \\
(0.0187)\end{array}$ & $\begin{array}{c}0.1360^{* * *} \\
(0.0187)\end{array}$ & $\begin{array}{l}0.0541^{\star *} \\
(0.0180)\end{array}$ & $\begin{array}{c}0.0758^{\star * *} \\
(0.0011)\end{array}$ \\
\hline ELEVATOR & $\begin{array}{c}0.0695 \\
(0.0401)\end{array}$ & $\begin{array}{c}0.0079 \\
(0.0422)\end{array}$ & $\begin{array}{c}0.1287 \\
(0.1104)\end{array}$ & $\begin{array}{c}0.0161 \\
(0.0446)\end{array}$ & $\begin{array}{c}-0.1336^{* *} \\
(0.0492)\end{array}$ & $\begin{array}{l}-0.0249 \\
(0.0436)\end{array}$ & $\begin{array}{c}0.0253 \\
(0.0256)\end{array}$ \\
\hline ROOMS & $\begin{array}{c}-0.2708^{* * *} \\
0.0161\end{array}$ & $\begin{array}{c}-0.2565^{\star * *} \\
(0.0189)\end{array}$ & $\begin{array}{c}-0.2929^{\star * *} \\
(0.0250)\end{array}$ & $\begin{array}{l}-0.2427^{\star} \\
(0.0216)\end{array}$ & $\begin{array}{c}-0.091^{\star * *} \\
(0.0019)\end{array}$ & $\begin{array}{c}-0.2384^{* * *} \\
(0.0187)\end{array}$ & $\begin{array}{c}-0.2798^{\star * *} \\
(0.0157)\end{array}$ \\
\hline FLOOR & $\begin{array}{c}-0.0617 \\
(0.05654)\end{array}$ & $\begin{array}{l}0.1484^{\star} \\
(0.0633)\end{array}$ & $\begin{array}{c}0.0852 \\
(0.0709)\end{array}$ & $\begin{array}{c}0.0438 \\
(0.0657)\end{array}$ & $\begin{array}{c}0.2984^{* * *} \\
(0.0074)\end{array}$ & $\begin{array}{l}-0.0107 \\
(0.0675)\end{array}$ & $\begin{array}{l}0.1189^{\star *} \\
(0.0399)\end{array}$ \\
\hline SEA & $\begin{array}{l}-0.00031 \\
(0.00075)\end{array}$ & $\begin{array}{c}-0.00070^{\star * *} \\
(0.00019)\end{array}$ & $\begin{array}{l}0.0017^{\star *} \\
(0.005519\end{array}$ & $\begin{array}{l}-0.00019 \\
(0.00021)\end{array}$ & $\begin{array}{c}-0.00076^{* * *} \\
(0.00019)\end{array}$ & $\begin{array}{l}-0.0003^{* *} \\
(-0.00010)\end{array}$ & $\begin{array}{c}4.677 \mathrm{e}-5 \\
(8.573 \mathrm{e}-5)\end{array}$ \\
\hline CBD & $\begin{array}{c}0.00051 \\
(0.00069)\end{array}$ & $\begin{array}{c}0.000132^{\star} \\
(0.000629)\end{array}$ & $\begin{array}{c}-0.0016^{\star *} \\
(0.0005349)\end{array}$ & $\begin{array}{l}0.00023 \\
(0.0002)\end{array}$ & $\begin{array}{l}0.00017^{\star *} \\
(6.175 \mathrm{e}-5)\end{array}$ & $\begin{array}{c}0.00010 \\
(9.64 \mathrm{e}-5)\end{array}$ & $\begin{array}{l}-0.0002^{\star *} \\
(7.082 \mathrm{e}-5)\end{array}$ \\
\hline GREEN & $\begin{array}{c}0.00049^{* * *} \\
(0.00012)\end{array}$ & $\begin{array}{c}-0.000495^{\star *} \\
(0.000185)\end{array}$ & $\begin{array}{c}1.089 e-6 \\
(0.6365 e-3)\end{array}$ & $\begin{array}{c}0.00004 \\
(0.00016)\end{array}$ & $\begin{array}{l}-0.00018 \\
(0.00023)\end{array}$ & $\begin{array}{l}7.77 \mathrm{e}-5 \\
(0.0001)\end{array}$ & $\begin{array}{c}-5.349 \mathrm{e}-5 \\
(0.00015)\end{array}$ \\
\hline TREAT & $\begin{array}{l}0.2943^{* *} \\
(0.1074)\end{array}$ & $\begin{array}{c}0.1873 \\
(0.1094)\end{array}$ & $\begin{array}{l}0.7863^{\star} \\
(0.3022)\end{array}$ & $\begin{array}{l}-0.0244 \\
(0.1102)\end{array}$ & $\begin{array}{l}0.2010^{\star} \\
(0.100)\end{array}$ & $\begin{array}{c}-0.7073^{* *} \\
(0.2201)\end{array}$ & $\begin{array}{l}0.4244^{*} \\
(0.1981)\end{array}$ \\
\hline AFTER & $\begin{array}{c}0.5759^{* * *} \\
0.0508\end{array}$ & $\begin{array}{l}0.756^{* * *} \\
(0.0751)\end{array}$ & $\begin{array}{c}0.4324^{\star * *} \\
(0.0757)\end{array}$ & $\begin{array}{c}0.8114^{* * *} \\
(0.0504)\end{array}$ & $\begin{array}{l}1.847^{\star * *} \\
(0.0574)\end{array}$ & $\begin{array}{c}0.8183^{* * *} \\
(0.1171)\end{array}$ & $\begin{array}{c}0.8264^{* * *} \\
(0.0321)\end{array}$ \\
\hline TREAT*AFTER & $\begin{array}{l}-0.0953 \\
(0.0692)\end{array}$ & $\begin{array}{l}-0.0298 \\
(0.0905)\end{array}$ & $\begin{array}{c}0.0641 \\
(0.0852)\end{array}$ & $\begin{array}{l}-0.1545 \\
(0.0857)\end{array}$ & $\begin{array}{c}-0.2703^{\star *} \\
(0.1018)\end{array}$ & $\begin{array}{c}0.1426 \\
(0.1310)\end{array}$ & $\begin{array}{c}-0.1597^{\star} \\
(0.0770)\end{array}$ \\
\hline Multiple $\mathrm{R}^{2}$ & 0.6885 & 0.6012 & 0.7302 & 0.7499 & 0.7855 & 0.664 & 0.8112 \\
\hline
\end{tabular}

The dependent variable is price (thousand $€$ ) per $\mathrm{m}^{2}$. The significance levels are ${ }^{* *}<0.001,{ }^{* *}<0.01,{ }^{*}<0.05$. The standard errors of coefficients are reported in brackets. 
information is provided by the variable TREAT^AFTER. This variable shows the effect of being located in both the treatment group and the "after" group. However, the effect remains insignificant in most cases. Only in case 5, the variable shows a more significant effect, but the effect is opposite to our assumption, suggesting lower prices for apartments being located in the treatment neighbourhood (after treatment). The specific nature of the case 5 neighbourhoods however suggests that the results do not necessarily indicate a negative price effect of infill development; In case 5, the treatment and control neighbourhoods are located on an island, which implies that attributes such as location close to the sea and high floor number are highly valued by the residents (as is also shown by the results of the regression analysis). Even more importantly, the on-going construction of a new metro line with a metro station in the central area of the island (which is also the location of the control neighbourhood) has supposedly, already since several years, provided a price premium for apartments located nearby.

Regarding other independent variables of our model, the impact of structural characteristics of the apartments/ buildings seems as expected: Larger room number leads to lower prices per $\mathrm{m}^{2}$ and the good condition of the apartment provides a significant price premium. Higher floor number in relation to total floor number has a positive significant effect on prices in a few cases but not in all. Also surprisingly, access to elevator does not have a significant effect implying that apartments in low-rise buildings might be more preferred than apartments in tall buildings.

The effect shown by the environmental variables are somewhat as expected. Decreasing distance to sea has a significant positive effect on prices in those neighbourhoods which are located close to the coastline, whereas in others the impact is insignificant. Distance to CBD has a similar effect in two cases but the opposite effect in one case (case 5). In case 5 this abnormality can be explained by the specific characteristics of the neighbourhood (already explained earlier), which are likely to affect prices more than distance to CBD. Although earlier research has suggested a positive price impact of parks and green areas, our analysis does not show a price premium provided by easy access to green areas. In case 1, the effect is even against the assumption suggesting that prices are higher in locations with longer distances to green areas. This can however be explained by the geography of the area; as the whole area is surrounded by woods, it is not surprising that a location closer to the centre of the area, and closer to services (and also further away from the woods), might be more preferable.

\section{Conclusions and discussion}

Only a rather limited number of studies have examined whether infill development affects the prices of existing housing. These studies differ from each other regarding the type of buildings considered (single-family houses or apartments), and most of the studies focus on the U.S. housing market covering a rather limited geographic area. Thus our study sheds light on a geographic area and a type of housing market which has so far been rather undiscovered, regarding the impact that infill development has on existing properties. All the selected case neighbourhoods are typical urban areas in the capital region of Finland, with a large number of residential apartment buildings built in the 60s, 70s and 80s. Even though our study is based on individual cases, we however do cover the capital area fairly well with case neighbourhoods spread over three cities (Helsinki, Espoo and Vantaa). During those years, a similar construction boom took place also in other European countries, and these buildings are currently facing challenges because of increasing renovation need, some also being in need of a "facelift". It has been suggested that infill development can have a crucial role regarding these issues, both by contributing to the upgrade of the neighbourhood as well as providing housing companies with a solution to finance their renovation. Hence, the results of our study are undoubtedly of interest to a number of different actors, who might be involved with processes related to infill development, ranging from individual apartment owners to city planners.

Our study examined the effect of infill development on the prices of existing apartments by using difference-indifference hedonic regression. We carried out the analysis for seven case neighbourhoods and appointed reference neighbourhoods and analysed whether prices before infill development were statistically different from prices after in the two neighbourhood groups. Overall, the results showed no significant difference in price development. Hence the results of our analysis indicate that infill development has no significant impact on prices of existing apartments. Only in one case a more significant effect of being located in the treatment group was observed, but in this case the regression analysis suggested a negative impact. However, given the specific nature of this neighbourhood (being located on an island and the new metro line being built in the control neighbourhood), this result should not be considered as indication of a negative price effect of infill development.

Our results are in line with most of the previous studies which also did not find strong or any correlation between infill development and changes in housing prices (Blanchard et al., 2008; Zahirovich-Herbert \& Gibler, 2014; Pollakowski et al., 2005). Only two studies are contradicting with our results suggesting a significant impact (Ooi \& Le, 2013; Mathur \& Ferrell, 2013) but these studies differ greatly from our research by the location of the studies (Singapore and California) and by the type of housing studied (single-family houses in the study by Mathur \& Ferrell, 2013).

To find explanations for the results, it is important to understand the specific nature of the property market. Attributes such as purchasing power, size and features of the neighbourhood affect the value of residential properties. Also, the general economic situation and development (such as economic recession or depression) affect the 
housing market as well as availability and cost of money. Earlier studies suggest that price development depends on a great number of characteristics and hence it is not surprising that infill development alone does not explain much of the price change.

The concepts of amenity effect (Ooi \& Le, 2013) and negative externalities are useful when reflecting the results. Even if infill development might create benefits for the residents of the neighbourhood by bringing along better services and improved access to public transportation, also negative externalities such as increasing density and deterioration of green areas may impose a negative impact on housing prices. Also, normally infill development is rather small scale and perhaps therefore cannot cause either amenity effect nor negative externalities, and this might be the reason for a modest price impact found in our case neighbourhoods.

A plausible explanation for our results may also be found from the perceptions that residents of Finnish neighbourhoods have about infill development. Arvola and Pennanen (2014) conducted a wide survey to study the attitudes and beliefs of Finnish urban residents regarding infill development, and found that residents have strongly negative beliefs about the effects that infill development will have on their neighbourhood. The common belief was that aspects related to neighbourhood identity, nature, traffic and safety will degenerate, whereas only services and transportation were expected to improve. Effect on property value was expected to be either neutral or slightly negative. As the market price of housing depends on the valuation and expectations of both seller and buyer, the negative attitudes and beliefs of one party indicate downward pressure to the sale price. Therefore, if residents have low expectations for neighbourhood improvements and housing price development after infill development, naturally these negative expectations are also reflected in the prices of sold properties. This is probably not the case in the neighbourhoods of our study as no significant negative effect of infill development was shown. However, the attitudes that Finnish residents have towards infill development might partly explain why infill development did not have any significant positive impact in the studied neighbourhoods.

\section{Limitations of the study}

A few limitations were recognised during the length of our study. A major limitation was that in some of the case neighbourhoods, the number of transactions was rather low although we used data provided by a Finnish transaction database in its entirety. This database is, however, the most comprehensive database for housing transactions in Finland and it is widely used in housing market studies. Thus we do recognise that a larger number of transactions might have led to more significant results but given the excellence of the database we think that the concise sample did not create an insurmountable limitation. Also, the volume of transactions could only have been enlarged by expanding the studied areas, but as the development areas in Finland are rather small, the impact would however have remained minor.

Also selecting the case neighbourhoods could have been done by using a more established method, such as propensity score matching. However, our research group is very familiar with the capital region where the case neighbourhoods are located, and therefore we decided to use our local knowledge for finding the cases. Also, the number of potential neighbourhoods was very limited and hence we do not think that any other selection method would have led to a better result.

\section{Acknowledgements}

This study was part of the Research on resident-driven infill development possibilities - case study in urban areas in Finland (REPSU) project funded by the Academy of Finland (Decision No. 255473).

\section{References}

Alonso, W. (1964). Location and land use. Cambridge: Harvard University Press.

https://doi.org/10.4159/harvard.9780674730854

Angrist, J. D., \& Pischke, J.-S. (2008). Mostly harmless econometrics: an empiricist's companion. Princeton University Press.

Arvola, A., \& Pennanen, K. (2014, October). Understanding residents' attitudes towards infill development at Finnish urban suburbs. World Sustainable Building Conference (WSB14). Barcelona. ISBN: 978-84-697-1815-5.

Baum-Snow, N. (2007). Suburbanization and transportation in the monocentric model. Journal of Urban Economics, 62, 405423. https://doi.org/10.1016/j.jue.2006.11.006

Bertaud, A. (2004). The spatial organization of cities: deliberate outcome or unforeseen consequence? World development report 2003: dynamic development in a sustainable world. World Bank. Retrieved from http://alainbertaud.com/wp-content/ uploads/2013/06/AB_The_spatial_organization_of_cities_ Version_31.pdf

Biddle, T., Bertoia, S., Greaves, S., \& Stopher, P. (2006). The costs of infill versus greenfield development - a review of recent literature: a review of recent literature. $29^{\text {th }}$ Australian Transport Review. 29 ${ }^{\text {th }}$ Australian Transport Research Forum, Gold Coast, Queensland, Australia.

Blanchard, C., Clegg, E., \& Martin, L. (2008). The consequences of residential infill development on existing neighborhoods in the Treasure Valley. Project Report. Urban Land Institute, Idaho/Smart Growth, Idaho, Boise, Idaho, USA. Retrieved from http://www.idahosmartgrowth.org/app/uploads/2014/05/ uliisg_infill_report.pdf

Brennan, M., Olaru, D., \& Smith, B. (2014). Are exclusion factors capitalised in housing prices?. Case Studies on Transport Policy, 2(2), 50-60. https://doi.org/10.1016/j.cstp.2014.05.002

Camagni R., \& Capello R. (2008). An ex-ante evaluation of an urban project through property value increases: an hedonic price approach. In A. Khakee, A. Hull, D. Miller, \& J. Woltjer (Eds.), 2008: New Principles in Planning Evaluation (pp. 103137). Ashagate, Aldershot.

Card, D., \& Krueger, A. B. (1994). Minimum wages and employment: a case study of the fast-food industry in New Jersey 
and Pennsylvania. American Economic Review, 84(4), 772793.

Ciccione, A. (2002). Agglomeration effects in Europe. European Economic Review, 46(2), 213-227.

https://doi.org/10.1016/S0014-2921(00)00099-4

Clark, T. A. (2013). Metropolitan density, energy efficiency and carbon emissions: multi-attribute tradeoffs and their policy implications. Energy Policy, 53, 413-428.

https://doi.org/10.1016/j.enpol.2012.11.006

Cortright, J. (2009). Walking the walk: how walkability raises home values in U.S. cities. CEOs for Cities. Retrieved from http://blog.walkscore.com/wp-content/uploads/2009/08/WalkingTheWalk_CEOsforCities.pdf

Damigos, D., \& Anyfantis, F. (2011). The value of view through the eyes of real estate experts: a fuzzy Delphi approach. Landscape and Urban Planning, 101(2), 171-178.

https://doi.org/10.1016/j.landurbplan.2011.02.009

Day, B. H. (2001). The theory of hedonic markets: obtaining welfare measures for changes in environmental quality using hedonic market data. Centre for Social and Economic Research on the Global Environment (CSERGE): London, UK. Retrieved from http://discovery.ucl.ac.uk/17583/1/17583.pdf

Debrezion, G., Pels, E., \& Rietveld, P. (2007). The impact of railway stations on residential and commercial property value: a meta-analysis. Journal of Real Estate Finance and Economics, 35(2), 161-180.

https://doi.org/10.1007/s11146-007-9032-z

Des Rosiers, F., Lagana, A., \& Thériault, M. (2001). Size and proximity effects of primary schools on surrounding house values. Journal of Property Research, 18(2), 149-168. https://doi.org/10.1080/09599910110039905

Dye, R. F., \& McMillen, D. P. (2007). Teardowns and land values in the Chicago metropolitan area. Journal of Urban Economics, 61(1), 45-63. https://doi.org/10.1016/j.jue.2006.06.003

Ellen, I. G., Susin, S., Schwartz, A. E., \& Schill, M. (2001). Do homeownership programs increase property value in low income neighborhoods? Low-Income Homeownership Working Paper Series, LIHO-01.13. Joint Center for Housing Studies Harvard University.

Espey, M., \& Lopez, H. (2000). The impact of airport noise and proximity on residential property values. Growth and Change, 31(3), 408-419. https://doi.org/10.1111/0017-4815.00135

Falkenbach, H., \& Nuuja, K. (2007, May). Flat ownership and registration in Europe, an overview. In Strategic Integration of Surveying Services, FIG Working Week 2007, Hong Kong SAR, China, 2007. Retrieved from https://www.fig.net/pub/ fig2007/papers/ts_1c/ts01c_04_falkenbach_nuuja_1276.pdf

Fejarang, R. A. (1994, January). Impact on property values: a study of the Los Angeles metro rail. Preprint, Transportation Research Board, $73^{\text {rd }}$ Annual Meeting, 1994. Washington, D.C.

Forrest, D., Glen, J., \& Ward, R. (1996). The impact of light rail system on the structure of house prices. Journal of Transport Economics and Policy, 30(1), 15-29.

Gibbons, S., \& Machin, S. (2005). Valuing rail access using transport innovations. Journal of Urban Economics, 57(1), 148169. https://doi.org/10.1016/j.jue.2004.10.002

Glaeser, E. L., \& Kahn, M. E. (2010). The greenness of cities: carbon dioxide emissions and urban development. Journal of Urban Economics, 67, 404-418.

https://doi.org/10.1016/j.jue.2009.11.006

Haaland, C., \& Bosch, C. K. (2015). Challenges and strategies for urban green-space planning in cities undergoing densification: a review. Urban Forestry \& Urban Greening, 14(4), 760-771. https://doi.org/10.1016/j.ufug.2015.07.009
Han, J. H., \& Elliott, P. (2013, May). Impact of high voltage overhead transmission lines on property value. In S. L. Kajewski, K. Manley, \& K. D. Hampson (Eds.), Proceedings of the $19^{\text {th }}$ CIB World Building Congress, Brisbane 2013: Construction and Society. Brisbane, Australia, Queensland University of Technology.

Hülagü, T., Kızılkaya, E., Özbekler, A. G., \& Tunar, P. (2015). A hedonic house price index for Turkey. Central Bank of the Republic of Turkey. Retrieved from https://www.bis.org/ifc/ events/ifc_isi_2015/424_huelague_paper.pdf

Jun, M.-J. (2012). Redistributive effects of bus rapid transit (BRT) on development patterns and property values in Seoul, Korea. Transport Policy, 19(1), 85-92. https://doi.org/10.1016/j.tranpol.2011.09.003

Kay, A. I., Noland, R. B., \& DiPetrillo, S. (2014). Residential property valuations near transit stations with transit-oriented development. Journal of Transport Geography, 39, 131-140. https://doi.org/10.1016/j.jtrangeo.2014.06.017

Kholdy, S. K., Muhtaseb, M. R., \& Yu, W. (2014). Effect of an open-air, mixed-use shopping center on the prices of nearby residential properties. Journal of Real Estate Practice and Education, 17(1), 1-18.

Ki, C. O., \& Jayantha, W. M. (2010). The effects of urban redevelopment on neighbourhood housing prices. International Journal of Urban Sciences, 14(3), 276-294. https://doi.org/10.1080/12265934.2010.9693685

Kong, F., Yin, H., \& Nakagoshi, N. (2007). Using GIS and landscape metrics in the hedonic price modeling of the amenity value of urban green space: a case study in Jinan City, China. Landscape and Urban Planning, 79(3-4), 240-252. https://doi.org/10.1016/j.landurbplan.2006.02.013

Kovacs, K. F. (2012). Integrating property value and local recreation models to value ecosystem services from regional parks. Landscape and Urban Planning, 108(2-4), 79-90. https://doi.org/10.1016/j.landurbplan.2012.08.002

Krause, A. L., \& Bitter, C. (2012). Spatial econometrics, land values and sustainability: trends in real estate valuation research. Cities, 29(2), 519-525.

https://doi.org/10.1016/j.cities.2012.06.006

Kytö, H., Kral-Leszczynska, M., Tuorila, H., \& Kiuru, J. (2014). Asuinalueiden elinkaarikestävyys pääkaupunkiseudulla [Lifespan sustainability of residential areas in the Helsinki Metropolitan Region]. Consumer Society Research Centre, Helsinki (in Finnish).

Laakso, S. (2012). Kaupunkien erikoistuminen ja kaupunkien verkostot [Specialisation of cities and cities' networks]. In $\mathrm{H}$. Loikkanen, S. Laakso, \& I. Susiluoto (Eds.), Metropolialueen talous. Näkökulmia kaupunkitalouden ajankohtaisiin aiheisiin. City of Helsinki Urban Facts. Retrieved from http://www.helsinki.fi/kaupunkitutkimus/dokumentit/metropolialueen_talous.pdf (in Finnish).

Litman, T. A. (2014). Economic value of walkability. Victoria Transport Policy Institute. Retrieved from http://www.vtpi. org/walkability.pdf

Lönnqvist, H. (2015). On the effects of urban natural amenities, architectural quality and accessibility to workplaces on housing prices: an empirical study on the Helsinki Metropolitan Area (Doctoral thesis). Aalto University, School of Engineering. City of Helsinki Urban Facts. Research Series 2015:5. Retrieved from https://aaltodoc.aalto.fi/bitstream/handle/123456789/19775/ isbn9789523310186.pdf? sequence $=1$ \&is Allowed $=y$

Mathur, S., \& Ferrell, C. (2013). Measuring the impact of sub-urban transit-oriented developments on single-family home values. Transport Research Part A: Policy and Practice, 47, 42-55. 
Matthews, P., Bramley, G., \& Hastings, A. (2015). Homo economicus in a big society: understanding middle-class activism and NIMBYism towards new housing developments. Housing, Theory and Society, 32(1), 54-72.

https://doi.org/10.1080/14036096.2014.947173

McConnell, V., \& Wiley, K. (2010). Infill development: perspectives and evidence from economics and planning. Resources for the Future. Washington, D.C. Retrieved from http://www. rff.org/rff/documents/RFF-DP-10-13.pdf

McMillen, D. P., \& McDonald, J. (2004). Reaction of house prices to a new rapid transit line: Chicago's midway line, 1983-1999. Real Estate Economics, 32(3), 463-486. https://doi.org/10.1111/j.1080-8620.2004.00099.x

Mills, E. S. (1967). An aggregative model of resource allocation in a metropolitan area. American Economic Review, 57(2), 197-210.

Ministry of the Environment. (2016). Asuntoalueiden kunnallistekniikan rakentamiseen myönnettävä määräaikainen valtionavustus [Temporary government subsidies for constructing infrastructure for residential areas]. Memorandum. 6.4.2016.

Muth, R. F. (1969). Cities and housing: the spatial pattern of urban residential land use. Chicago, IL: University of Chicago Press.

Nahlik, M. J., \& Chester, M. V. (2014). Transit-oriented smart growth can reduce life-cycle environmental impacts and household costs in Los Angeles. Transport Policy, 35, 21-30. https://doi.org/10.1016/j.tranpol.2014.05.004

Newell, T. A. (2010). Development and neighborhood revitalization: the effects of residential investment on property values in Durham, NC. Michigan Journal of Business, 2(2), 97-120.

Nykänen, V., Lahti, P., Knuuti, A., Hasu, E., Staffans, A., Kurvinen, A., Niemi, O., \& Virta, J. (2013). Urban infill and residential redevelopment. VTT Technology 97. 162 p. + app. 3 p. Espoo. Retrieved from http://www.vtt.fi/inf/pdf/technology/2013/T97.pdf

Nykänen, V., Lahti, P., Knuuti, A., Kurvinen, A., Niemi, O., \& Vihola, J. (2012). Tammelan täydennysrakentamisen edullisuus [Affordability of infill development in Tammela]. VTT Technical Research Centre of Finland, VTT-CR-04035-12 (in Finnish).

Ooi, J. T. L., \& Le, T. T. T. (2013). The spillover effects of infill developments on local housing prices. Regional Science and Urban Economics, 43(6), 850-861.

https://doi.org/10.1016/j.regsciurbeco.2013.08.002

Piekkola, H., \& Susiluoto, I. (2012). Kaupunkialueiden taloudellinen kasvu ja aineettoman pääoman merkitys alueilla [Economic growth of cities and the significance of immaterial capital in these regions]. In H. Loikkanen, S. Laakso, \& I. Susiluoto (Eds.), Metropolialueen talous. Näkökulmia kaupunkitalouden ajankohtaisiin aiheisiin. City of Helsinki Urban Facts. Retrieved from http://www.hel.fi/hel2/tietokeskus/julkaisut/ pdf/12_06_11_Erityisjulkaisu.pdf (in Finnish).

Pollakowski, H. O., Ritchay, D., \& Weinrobe, Z. (2005). Effects of mixed-income, multi-family rental housing developments on single family housing values. Cambridge, MA: Massachusetts Institute of Technology, Center for Real Estate Research. Retrieved from http://community-wealth.org/sites/clone.community-wealth.org/files/downloads/paper-pollatowski-et-al.pdf

Rosen, S. (1974). Hedonic prices and implicit markets: product differentiation in pure competition. Journal of Political Economy, 82, 34-55. https://doi.org/10.1086/260169

Rosenthal, S. S., \& Strange, W. C. (2004). Chapter 49: Evidence on the nature and sources of agglomeration economies, Handbook of Regional and Urban Economics, 4, 2119-2171. https://doi.org/10.1016/S1574-0080(04)80006-3

Ryan, B. D., \& Weber, R. (2007). Valuing new development in distressed urban neighbourhoods. Journal of the American Planning Association, 73(1), 100-111. https://doi.org/10.1080/01944360708976139

Santaoja, T. (2004). Täydennysrakentaminen kaupungin ja asuinympäristön kehittämisessä [The role of infill construction in city and neighbourdhood development]. City of Helsinki, City Planning Department, Reports 2004:3.

Seppälä, T. (2013). Täydennysrakentamisen haasteet ja talous-, energia- ja ympäristövaikutukset [Challenges and economic, energy and environmental impacts of infill building]. Licentiate thesis. Aalto University, School of Engineering. Retrieved from http://www.uudistuvakaupunki.fi/wordpress/ wp-content/uploads/seppala_lisuri_aaltoyliopisto_linkedin.pdf Thamrongsrisook, C. (2011). The influence of rapid transit systems on condominium prices in Bangkok. A hedonic price model approach. Thesis no. 105. KTH, School of architecture and the built environment. Retrieved from https://www. kth.se/polopoly_fs/1.186297!/Menu/general/column-content/ attachment/105.pdf

Tse, R. Y. C., \& Love, P. E. D. (2000). Measuring residential property values in Hong Kong. Property Management, 18(5), 366-374. https://doi.org/10.1108/02637470010360669

Tyrväinen, L. (1999). Monetary valuation of urban forest amenities in Finland. Academic dissertation. Finnish Forest Research Institute, Research Papers, 739, 53-76.

Votsis, A., \& Perrels, A. (2016). Housing prices and the public disclosure of flood risk: a difference-in-differences analysis in Finland. Journal of Real Estate Finance and Economics, 53(4), 450-471. https://doi.org/10.1007/s11146-015-9530-3

Wen, H., Zhang, Y., \& Zhang, L. (2014). Do educational facilities affect housing price? An empirical study in Hangzhou, China. Habitat International, 42, 155-163. https://doi.org/10.1016/j.habitatint.2013.12.004

Zahirovich-Herbert, V., \& Gibler, K. (2014). The effect of new residential construction on housing prices. Journal of Housing Economics, 26, 1-18. https://doi.org/10.1016/j.jhe.2014.06.003

Zhang, M., Meng, X., Wang, L., \& Xu, T. (2014). Transit development shaping urbanization: evidence from the housing market in Beijing. Habitat International, 44, 545-554. https://doi.org/10.1016/j.habitatint.2014.10.012 